\title{
RAZÃO E VIOLÊNCIA EM ERIC WEIL
}

\author{
Paulo César Nodari ${ }^{1}$ \\ Universidade de Caxias do Sul (UCS) \\ https://orcid.org/0000-0002-0482-6067
}

\section{RESUMO:}

O objetivo principal deste artigo é apresentar alguns dos principais argumentos de Eric Weil que sustentam a relevante tese da importância da escolha livre e deliberada do ser humano pela vida racional, demonstrando, por conseguinte, ser razoável a busca por uma existência cada vez mais humanizada e alicerçada sobre valores fundamentais da vida humana, tais como, a honestidade, a justiça e a felicidade, possibilitando, paulatina e progressivamente, a superação e o desaparecimento, tanto quanto possível, dos diferentes tipos de violência, estando o ser humano ciente, no entanto, de que a erradicação total da violência no mundo é impensável, uma vez ser a liberdade do ser humano um processo de contínua deliberação e escolha, tanto em nível pessoal, como também, comunitário e social.

PALAVRAS-CHAVE: Weil; Razão; Violência; Escolha; Liberdade.

\section{REASON AND VIOLENCE IN ERIC WEIL}

\begin{abstract}
:
The main objective of this article is to present some of the main arguments by Eric Weil that support the relevant thesis of the importance of free and deliberate choice of human beings for rational life. This demonstrates, therefore, that it is reasonable to search for a more and more humanized existence, founded on fundamental values of human life, such as honesty, justice and happiness. This makes gradually and progressively possible to overcome and to deter, as far as possible, different types of violence. However, human beings are aware that total eradication of violence in the world is unthinkable, since freedom of human beings is a process of continuous deliberation and choice, at personal, communal and social level.
\end{abstract}

KEY WORDS: Weil; Reason; Violence; Choice; Freedom.

\footnotetext{
${ }^{1}$ Doutor em Filosofia pela Pontifícia Universidade Católica do Rio Grande do Sul (PUCRS), Rio Grande do Sul - Brasil. Professor da Universidade de Caxias do Sul (UCS), Rio Grande do Sul - Brasil. E-mail: paulocesarnodari@hotmail.com
}

NODARI, Paulo César. Razão e violência em Eric Weil. Griot : Revista de Filosofia, Amargosa, Bahia, v.16, n.2, p.188204 , dezembro/2017. 
Eric Weil nasceu em 1904, na Alemanha, e, em 1933, abandona a Alemanha e vai à França, tendo obtido a nacionalidade francesa neste mesmo ano. Combate os horrores do nazismo e conhece o cativeiro durante 5 anos. Entre 1950 e 1977, leciona em algumas universidades francesas, em Lille, de 1956 a 1968, e, em Nice, até sua morte em 1977. Suas principais obras são: Lógica da filosofia (1950), Filosofia política (1956), Filosofia moral (1961), Ensaios e conferências (1970-1971), Problemas kantianos. Este alemão, naturalizado francês, ocupa na atualidade uma posição muito singular e relevante no estudo filosófico, apesar de, no Brasil, e, também, no mundo, ser ainda pouco conhecido. Seu pensamento filosófico centraliza-se na reflexão em torno da violência. Por conviver de perto as atrocidades de guerras e extermínios que marcaram profundamente o século $\mathrm{XX}$, Weil elabora uma reflexão filosófica muito peculiar, e, eminentemente, interessante e atual.

\title{
Escolha razoável
}

No que se refere à pesquisa e à reflexão sobre a violência, os textos de Weil são considerados uma obra-prima de nosso tempo. Na obra, Lógica da filosofia, Weil afirma: ser humano é um animal dotado de razão e de linguagem, mais exatamente de linguagem racional (WEIL, 2012, p. 11), sendo este esforço do ser humano em pensar, falar e viver de forma racional que caracteriza o pensamento filosófico. A filosofia tem como objetivo tornar o ser humano livre e capaz de justificar sua vida racionalmente, justamente, porque ele pode não sê-lo ou não querer vir a sê-lo, uma vez que ele, enquanto dotado de razão e de linguagem razoável, para que venha a ser o que ele está disposto a tornar-se, como alguém que deve realizar-se. Trata-se, pois, segundo Weil, da dialética da definição do ser humano enquanto capaz e possibilitado de realização. Assevera Weil:

\begin{abstract}
Basta projetar o que acabamos de dizer num único e mesmo plano para desembocar em afirmações paradoxais e "dialéticas". A simples justaposição das teses nos autorizará, então, a descrever o homem como o ser que é aquilo que ele não é, e que não é aquilo que ele é: ele é natureza dada e descritível, ao mesmo tempo em que está em busca de seu verdadeiro, que nunca é dado nem pode ser descrito; ele é essencialmente razão e linguagem razoável, ao mesmo tempo em que sempre está abaixo do nível da razão. Mais que isso, e bem pior: ele é até mesmo o ser que não é, visto que ele é essencialmente seu próprio devir, e que esse devir não é um devir natural e descritível, mas seu próprio fazer-se. (WEIL, 2012, p. 14-15: grifo do autor).
\end{abstract}

Percebe-se em Weil, a compreensão de que o ser humano é dotado de possibilidades semelhantes e distintas dos outros animais. Ele é um ser como os outros, isto é, tem necessidades, mas, também, tem desejos que ele próprio formou e deu para si (WEIL, 2012, p. 17). Ele, muitas vezes, não sabe o que quer, porém, sabe muito bem o que ele não quer. "Ora, o sentido dessa formulação torna-se agora definido: o homem não é aquilo que é, porque ele não quer aquilo que ele é, porque ele não está contente em

NODARI, Paulo César. Razão e violência em Eric Weil. Griot : Revista de Filosofia, Amargosa, Bahia, v.16, n.2, p.188204, dezembro/2017. 
ser o que ele é, em ter o que é. Ele é o animal que fala, um dos animais que fala, mas é o único animal que emprega a linguagem para dizer não." (WEIL, 2012, p. 18: grifo do autor). Dito de outro modo, diferentemente dos animais, tal como a abelha, que também transforma o que lhe é dado de modo natural e que há muito é possível de observação e constatação na natureza, o ser humano é capaz de transformação reflexiva, é artesão de si, ou ainda, é capaz de dizer não ao que, simplesmente, lhe é dado. Ele é capaz de linguagem razoável. "Ser razoável significa: ser capaz de realizar sua própria negatividade, não apenas dizer não àquilo que é, mas produzir daquilo que é o que ainda não era, um novo objeto, um novo procedimento, ambos liberados daquilo que era incômodo na coisa e no modo de transformação oferecidos pela natureza." (WEIL, 2012, p. 19: grifo do autor).

O pensamento proposto por Weil busca refletir sobre a questão da violência e em que medida ela pode ser considerada como que a mola propulsora da vida razoável. Na obra, Lógica da filosofia, ele procura compreender o ser humano e como é possível ele vir a tornar-se violento. $O$ ser humano é um ser capaz de razão e de violência. Ele é animal no sentido de ter em si uma tendência de agir ou com base nos instintos, tendências cegas e paixões ou de agir razoavelmente, porque lhe é possível escolher uma vida guiada pela razão. $O$ ser humano, enquanto ele é se constitui como ser de possibilidades, pode optar agir guiado pela razão ou não, lembrando que a opção pela ação racional é escolha pela realização da condição humana. A tarefa da filosofia consiste na formação e na constituição do ser humano capaz de escolher e agir racionalmente, pois a violência, em última análise, seria a recusa da ação racional. Para Weil, segundo Perine, a violência e a filosofia representam uma compreensão dialética da constituição da vida humana. "Violência e filosofia são tão intimamente relacionadas que não se compreende uma senão pela outra, e elas estão de tal modo implicadas na existência humana que não se a compreende sem elas. De fato, enquanto ser natural, o homem é violento, mas este ser violento se compreende e, por este mesmo fato, ele não é pura violência." (PERINE, 1987, p. 136: grifos do autor). Nessa linha de pensamento, pergunta-se Weil:

O que é o homem? Uma vez mais, é preciso perguntá-lo: ele não é o animal dotado de linguagem razoável, dotado no sentido em que é dotado de mãos ou de estação vertical; tampouco é artesão e fabricante, no sentido em que a abelha o é; se ele é próprio, ele é razão, não apenas razoável, mas razão encadeada num corpo de animal, corpo indigente, corpo que tem necessidades, tendências cegas, paixões. Seu trabalho verdadeiramente humano consiste na transformação desse ser composto, no intuito reduzir, tanto quanto possível, a parte que não é razoável, a fim de que, por inteiro, seja razão. Por certo ele não será completamente bem-sucedido, em absoluto; sempre terá de arrasta um resto de animalidade; jamais será totalmente razão; mas algumas vezes o será, algumas vezes será livre; algumas vezes, por alguns instantes, será deus, estará presente diante do mundo presente, positividade pela negação da negatividade inconsciente; e é por esses instantes de suprema felicidade, de plenitude indizível, inenarrável, que ele viverá, que ele aceitará, como homem, o incômodo do qual o animal dentro dele jamais escapará. Ele poderá se calar,

NODARI, Paulo César. Razão e violência em Eric Weil. Griot : Revista de Filosofia, Amargosa, Bahia, v.16, n.2, p.188204, dezembro/2017. 
não porque desistiu, mas porque conseguiu; já não se servirá da razão, não porque se tornaria não razoável, mas porque se tornou razão. (2012, p. 22).

Violência, para Weil, está ligada a uma atitude do ser humano não querer assumir e justificar sua vida racionalmente, confortando-se com o agir à maneira das forças naturais, deixando-se dominar pelas suas tendências, instintos, necessidades. Uma vez que o ser humano não é nem naturalmente bom e nem naturalmente mau. Ou seja, com outras palavras, Weil assume o posicionamento intelectual de que o ser humano não estaria, de antemão, determinado a ser bom ou mau, mas, antes, estaria em uma condição como que de indeterminação original. $O$ ser humano não é nem um deus e nem um animal, ele acaba por assumir a disposição de não escolher deliberadamente a opção pela vida racional, privando-se da razão, e, assumindo a violência, isto é, a ação guiada e conduzida à maneira das forças naturais, dominado que é pelas suas tendências, instintos, necessidades (PERINE, 1987, p. 206).

$O$ ser humano, ao assumir deixar-se guiar pela violência e não pela razão acaba por assumir o caminho de negação do apaziguamento de si e de realização enquanto tal. "A violência é suscetível de assumir várias formas, mas todas elas confluem na rejeição da busca pelo apaziguamento, se erguem contra a perspectiva de uma reconciliação do homem consigo mesmo." (SAVADOGO, 2016, p. 193). A violência representa a irracionalidade, o impedimento do ser humano viver sua humanidade plenamente, uma vez que, como afirma Weil: "[...] os homens não costumam dispor da razão e da linguagem razoável, mas devem delas dispor para serem homens plenamente." (2012, p. 14). Por isso, a violência é uma atitude que contradiz a exigência de humanidade inerente ao ser humano, uma vez que a escolha pelo caminho da violência e não pela da razão acaba por desumanizá-lo. Para que o ser humano se torne humano, realizado, e feliz, ele deve optar livremente pela razão e trabalhar incessantemente contra a violência se ele quiser sentir-se realizado enquanto tal. Acentuando a relevância do ensejo de humanizar o humano, torna-se muito oportuna a definição de Herder (17441803):

Destarte, gostaríamos de ficar com a palavra humanidade [Humanität], conceito tão digno ao qual aderiram os melhores escritores, dentre os velhos e os novos. Humanidade é o caráter de nosso gênero; no entanto, ele está presente em nós apenas como estrutura, e precisa ser efetivamente cultivado em nós. Nós não o trazemos pronto conosco ao mundo; mas ele deve ser a meta de nosso encargo no mundo, a soma de nossas atividades, nosso valor: pois não conhecemos nenhum caráter angelical no ser humano, e, se o demônio que nos rege não é nenhum demônio humano, nós nos tornamos os importunadores dos seres humanos. O divinal em nosso gênero, portanto, é a formação para a humanidade [Bildung zur Humanität]; todos os grandes e bons seres humanos, legisladores, inventores, filósofos, poetas e artistas, todo e qualquer ser humano nobre em sua capacidade contribui para essa formação com a educação de suas crianças, com a observação de seus deveres, por meio de exemplos, obras, institutos e doutrinas. A humanidade é o tesouro e o produto de todos os esforços humanos, ela é como que a arte de nosso gênero. Sua

NODARI, Paulo César. Razão e violência em Eric Weil. Griot : Revista de Filosofia, Amargosa, Bahia, v.16, n.2, p.188204, dezembro/2017. 
formação é uma obra que precisa ser incessantemente desenvolvida; ou então, desceremos de volta para patamares mais ou menos semelhantes aos da crua animalidade, da brutalidade. (HERDER, 2011, p. 73-74: grifos do autor).

A escolha entre a razão e a violência está intrinsecamente conectada à liberdade. O ser humano é capaz de razão e de violência, sendo-lhe possível escolher tanto uma quanto outra. A escolha pela violência é o oposto à escolha pela razão. Todavia, segundo Perine, o sentido da definição do ser humano como razão somente se mostraria, de fato, na realização da razão, na medida em que ele é capaz de dizer não aos seus desejos e necessidades, especialmente, os que o privariam de uma vida razoável. Dentre os animais, ele é o único capaz de satisfazer os desejos e as necessidades que ele mesmo criou (PERINE, 1987, p. 126). Numa palavra, ele tem interesse de satisfazer a necessidade e o desejo, o que implica afirmar a vitória do contentamento sobre o descontentamento (PERINE, 1987, p. 127), ou seja, “[...] só é legítimo o desejo que busca a razão e o contentamento." (WEIL, 2012, p. 35).

Aqui, no entanto, antes de avançar, urge esclarecer, ainda que brevemente, a ideia supracitada de que "[...] só é legítimo o desejo que busca a razão e o contentamento.". Primeiro, sabe-se, por muitas e dolorosas experiências históricas, que a razão, quando mal intencionada e direcionada, pode, também, ser de capacidade de violência inominável. Basta situar, por exemplo, toda a crítica descerrada à razão instrumental e à razão dominadora, deferida, tanto pelos autores da nominada Teoria Crítica, como também, pelos pensadores denominados de rebeldes, especialmente, Foucault, Deleuze e Derrida, sem, contudo, deixar no esquecimento importantes autores, sobremaneira do século $\mathrm{XX}$, dentre outros, das correntes do pensamento existencialista, do pensamento personalista e do pensamento da alteridade. Segundo, é importante ter em mente que contentamento pode dar margem a diferentes interpretações, mas, para Weil, nesse caso, ao contentamento aufere-se a tese do razoável contentamento, isto é, da busca de sua realização enquanto ser humano razoável que é. Assevera Weil:

\begin{abstract}
Se o homem é o ser que não se contenta com o dado, tampouco se contentará com esse ser dado que é o seu e que consiste em negar o dado. Uma vez que uma natureza do homem é dada, ela será transformada pela atividade do homem; uma vez que o caráter do homem é dado - e é o que acontece na e pela linguagem do filósofo -, o homem, sendo negador de todo dado, fica descontente com esse ser que pretende ser o seu. Ele só o expressa para superálo, para transformá-lo, para negá-lo - para negar a si mesmo; uma vez que sua vida é compreendida por ele como expressão agente de seu descontentamento, ele se erguerá contra esse mesmo descontentamento e contra essa mesma atividade: ele já não buscará se desvencilhar do que o descontenta, mas criará o contentamento pela vitória sobre esse mesmo descontentamento e essa mesma negatividade. (WEIL, 2012, p. 20: grifo do autor).
\end{abstract}

Ao renunciar a uma vida razoável, o ser humano submeter-se-ia a sua animalidade, às suas paixões e tendências cegas, renunciando sua liberdade. É optando

NODARI, Paulo César. Razão e violência em Eric Weil. Griot : Revista de Filosofia, Amargosa, Bahia, v.16, n.2, p.188204, dezembro/2017. 
por uma vida justificada, uma vida racional, que o homem viverá sua liberdade e sua própria humanidade. Assim, a razão se apresenta como condição para a liberdade. Ela faz o ser humano libertar-se de sua condição de animal irracional, para assumir uma vida justificada e razoável. A não escolha pela razão conduz o ser humano à violência, sendo, pois, uma atitude irracional, e, constituindo-se em um obstáculo à realização de sua própria humanidade. Entretanto, lembra-se que o ser humano só pode reconhecer-se como ser violento, porque é um ser dotado de razão, descobrindo-se como violento, porque ele traz em si a exigência de não ser violento, ou seja, a própria exigência da razão. "A razão é uma possibilidade do homem: possibilidade, isso designa o que o homem pode, e o homem pode certamente ser razoável, ao menos querer ser razoável. Mas isso é apenas uma possibilidade, não uma necessidade, e é possibilidade de um ser que possui ao menos outra possibilidade. Sabemos que essa outra possibilidade é a violência." (WEIL, 2012, p. 87: grifo do autor).

O ser humano é um ser capaz de razão e de violência. E em sendo a razão constitutiva da própria humanidade de cada um e de toda a humanidade, o desejo de universalidade é o desejo da parte da razão e não da violência. $O$ ser humano não pode aproximar-se da universalidade a não ser fazendo a opção pela não-violência. Nesse sentido, a não-violência é o ponto de partida, a condição e o objetivo de toda a filosofia e de todo filósofo. Logo, segundo Weil, o ser humano que optou pela razão e pela não violência deverá enfrentar a violência manifesta na história e não pode deixar de entrar no campo da ação política, a fim de trabalhar pela chegada de um mundo em que a razão e a não-violência prevaleçam nas relações humanas. Lutar contra a violência é assumir na vida prática a opção contra a violência. $O$ ser humano que optou pela razão precisa agir no sentido de que a razão possa penetrar toda a existência do ser humano e de toda a humanidade (WEIL, 2012, p. 35). Sublinha Weil:

A linguagem é razoável se e quando ela permite essa intervenção do homem no dado, essa transformação da natureza - nada mais, nada menos: só a eficácia conta. Ser razoável significa: ser capaz de realizar sua própria negatividade, não apenas dizer não àquilo que é, mas produzir daquilo que é o que ainda não era, um novo objeto, um novo procedimento, ambos liberados daquilo que era incômodo na coisa e no modo de transformação oferecidos pela natureza. (WEIL, 2012, p. 19: grifo do autor).

Vê-se, então, que a filosofia tem o papel de auxiliar e possibilitar a reflexão com o intento de tornar o ser humano livre e capaz de justificar sua vida racionalmente. A filosofia é a atividade reflexiva que busca dar razões da importância da escolha livre e deliberada pela vida racional, sendo muito razoável a busca por uma vida humana cada vez mais humanizada e alicerçada sobre valores fundamentais da vida humana, tais como, a honestidade, a justiça e a felicidade, possibilitando, paulatina e progressivamente, a superação e o desaparecimento, tanto quanto possível, da violência, estando cientes, no entanto, de que a erradicação da violência é inimaginável (WEIL, 2012 , p. 34). O temor que alguém sente da violência é o medo contínuo em que cada um pode se perder, pode recair. Entretanto, a sensação mais intensa de medo relaciona-se,

NODARI, Paulo César. Razão e violência em Eric Weil. Griot : Revista de Filosofia, Amargosa, Bahia, v.16, n.2, p.188204, dezembro/2017. 
sobretudo, à insegurança que se tem diante da possibilidade sempre iminente de queda ou de recaída na irracionalidade, isto é, na violência. "A possibilidade de se perder, de decair, não de reincidir no desejo, mas de recuar diante do que ele não pode evitar, de esquecer o que é, em vista do que pode lhe acontecer: medo do medo." (WEIL, 2012, p. 34). Em outras palavras, pode-se afirmar com Perine: "A violência é uma possibilidade humana que permanece sempre como um outro da razão, como ameaça constante à razão, pois o seu princípio não pode ser eliminado pela razão." (PERINE, 2004, p. 151: grifo do autor).

O ser humano que, em sua liberdade, busca a vida racional, torna-se ser razoável, isto é, sábio. A vida do ser humano razoável é expressa como a sabedoria que se torna prática, isto é, a união da reflexão com a ação. O sábio é aquele que escolheu a vida razoável, e, por isso, sua ação na história será com base na razão, construindo relações razoáveis de convivência e de fortalecimento da não-violência, capacitando a cada um e a todos a assumirem sua condição da livre escolha do dizer contínua e progressivamente não à violência.

\title{
A ação moral
}

O ser humano, cuja vida alicerça-se na escolha pela razão, torna-se, de fato, um ser moral, livre e razoável. Sua opção pela razão torna-se opção pelo agir moral que se efetiva na decisão contínua e progressiva pela vida razoável, afirmando e reafirmando o seu não à violência. Urge salientar, no entanto, que, em Weil, a despeito do ponto de vista natural, poder-se-ia afirmar que o ser humano tenderia muito mais a ser violento, já que, muitas vezes, “[...] ele é dominado por suas tendências, instintos, necessidades." (WEIL, 2011, p. 19). Porém, afirma Weil, mais importante que perguntar se o ser humano é mau ou bom por natureza, trata-se de sublinhar a relevância da capacidade racional que lhe é intrínseca e da disposição do ser humano para o bem, por meio da educação. Assinala Weil na obra, Filosofia moral:

\begin{abstract}
Se a tese da maldade essencial do homem revela-se contraditória em si mesma, entretanto, ela é útil para relembrar ao seu crítico que o ser humano só é moral porque é, ao mesmo tempo, imoral: ele pode ser bom porque pode ser mau, e inversamente. Isso não quer dizer que as duas visões sejam falsas sob todos os aspectos; elas são verdadeiras, mas somente quando tomadas juntas. A experiência mais comum o confirma e a observação mostra isso em toda moral concreta, em todo sistema de regras que domine, ou pretenda dominar, a vida de uma comunidade histórica: em todos os lugares as crianças são educadas, os que são considerados essencialmente, isto é, irremediavelmente, ineducáveis, são eliminados, os que vivem segundo a moral (qualquer que seja o seu conteúdo concreto) são honrados. O homem não é naturalmente bom, mas também não é naturalmente mau; mais exatamente, quem possuísse uma ou outra dessas qualidades como se possui qualidades físicas não seria um homem, mas um animal ou um deus. $O$ indivíduo deve ser conduzido ao bem, deve ser educado - e, portanto, deve poder sê-lo - para querer o bem e para evitar o mal; se abstrairmos dessa educação, ele não nem bom nem mau, ele é, como se
\end{abstract}

NODARI, Paulo César. Razão e violência em Eric Weil. Griot : Revista de Filosofia, Amargosa, Bahia, v.16, n.2, p.188204, dezembro/2017. 
diz, amoral, não imoral, porque essa abstração o transforma em animal. (WEIL, 2011, p. 18: grifos do autor).

A moralidade é definida como capacidade de o ser humano ter uma consciência má ou boa. $O$ ser humano pode ser bom ou mau, moral ou imoral. "A moral afirma, pois, que todo homem tem em si tudo o que constitui a humanidade do homem." (WEIL, 2011b, p. 34). Assim, ele deve ser conduzido, educado para o bem, para vir a tornar-se moral. Ou seja, inata ao homem é a capacidade que lhe advém inerente de poder discernir entre o bem e o mal, entre o lícito e o ilícito. É por essa capacidade que o ser humano é um ser moral, isto é, ele tem capacidade de separar a maneira de como deve e a maneira de como não deve agir, atos que ele pode, com reflexão, aprovar ou desaprovar. $O$ ser humano, querendo assumir e enfrentar a difícil problematização da escolha, ou seja, de ter que escolher entre a possibilidade de ser bom ou mau, ele precisa tomar em conta a exigente realidade de que a escolha é a via de condução à vida livre e feliz. E como ele quer ser feliz, porque tem consciência de sua possibilidade de infelicidade, já que o caminho da felicidade e da realização não está, de antemão, garantido e realizado para ninguém, ele, enquanto um ser portador da capacidade intrínseca moral, ele quer libertar-se da condição animal, das paixões e alcançar a universalidade. Assevera Weil.

Estritamente falando, a ação do indivíduo que quer ser moral é ação sobre si mesmo; é no indivíduo que a razão deve prevalecer sobre a paixão, que o universal deve dominar e informar o particular: é a sua própria subjetividade que deve ser universalizada. Esse $E u$, não empírico, cuja tarefa é transformar o eu empírico, só se manifesta no sei de um eu empírico e só a ele se refere. É verdade que ele é um e único, sendo pura razão e pura universalidade, e, como tal, refere-se a todo eu empírico. Mas em cada eu é só a ele que se refere, e a luta da liberdade pela liberdade, embora sendo a mesma para todo homem, é a tarefa mais íntima e mais pessoal que pode existir. Todo indivíduo é chamado $\grave{a}$ liberdade, ’̀ razão, à moral, mas pela liberdade, pela razão, pela moral nele. (WEIL, 2011, p. 34: grifos do autor).

Essa vontade de universalidade está ligada aos termos razão e liberdade. " $O$ homem, enquanto visa à universalidade, é razoável; enquanto é capaz de universalidade, é liberdade: sendo capaz de razão, mas não sendo razão, ele é também capaz de optar contra a universalidade e contra a razão." (WEIL, 2011, p. 52). Ele vive sua condição como ser livre. Está aberto à possibilidade, à escolha de uma vida refletida ou de uma vida de violência, própria de sua condição de vida " [...] à maneira das forças naturais, determinado por elas e como elas, ele é dominado por suas tendências, instintos, necessidades [...]." (WEIL, 2011, p. 19). A razão e a violência só se separam da vida do ser humano quando este optar pela razão, de fato, ainda que o perigo da queda e da recaída sempre ronde a vida razoável. Tão-somente a escolha da razão dará ao ser humano a consciência do outro caminho, a violência. Só o ser humano que optou pela razão sabe que é livre, e escolhe livremente a razão, porque sabe que poderia ter optado pelo oposto da razão, a violência. "Decorre dessas reflexões que o homem escolhe

NODARI, Paulo César. Razão e violência em Eric Weil. Griot : Revista de Filosofia, Amargosa, Bahia, v.16, n.2, p.188204, dezembro/2017. 
livremente a razão, livremente porque ele teria podido, e pode, optar pelo oposto da razão, a violência." (WEIL, 2011, p. 57).

O ser humano está diante de dois caminhos, ou escolhe uma vida moral, fundada na razão e na vontade razoável, que o levará à felicidade, ou ele escolhe o oposto, uma vida não refletida, guiado por seus instintos, por suas necessidades e seus desejos, já que a vontade razoável guia a escolha do ser humano. Portanto, a distinção entre desejo e vontade, em Weil, torna-se imprescindível, uma vez que o desejo seria próprio da condição animal do ser humano, enquanto submissão aos seus instintos e tendências cegas, próprias de uma vida não refletida e irracional, ao passo que a vontade, por sua vez, estaria muito mais ligada à razão e à liberdade. A vontade de ser razoável é a não submissão àquilo que condicionaria o ser humano a deixar-se guiar pelo animal irracional. Sublinha Weil:

O homem é livre na medida em que não se submete, pura e simplesmente, imediatamente, ao que condiciona, interior exteriormente, o animal: assim, a vontade nada mais é do que o ser razoável e finito que pretende ser razoável na condição que é sua; ela não é uma faculdade do homem, ela é o próprio homem, que nela se torna homem, e que, tornando-se homem razoável, descobre a si mesmo livre de uma liberdade que nada pode constranger: até mesmo a renúncia à liberdade permanece um ato livre. (WEIL, 2011, p. 62-63: grifo do autor).

A vontade razoável guia a escolha, ela é o ser razoável do ser humano que se descobre livre e, por sua vez, com uma liberdade que lhe é infinita. Nesse sentido, é importante dar-se conta de que o mundo em que se vive não dá garantia de realização e de felicidade. A felicidade precisa ser buscada e construída. Ou seja, o mundo no qual está o ser humano é o mundo que pode torná-lo feliz ou também infeliz. Mesmo obtendo e conquistando tudo o que desejou e deseja o ser humano não tem garantia de que será feliz, uma vez que a satisfação de um desejo gera, por sua vez, novos desejos, e, assim, sucessiva e progressivamente. $O$ ser humano precisa assumir o caminho de construção pessoal, caminho este da razão e do enfrentamento dos desejos e do medo, enquanto ser racional, e, também, enquanto capaz de violência. Faz-se pertinente ao ser humano ter consciência de si e de suas possibilidades. Em outras palavras, afirma-se que o ser humano só pode dizer-se livre quando se sabe livre. "Só o homem razoável sabe que é livre; só aquele que se voltou para a razão pode compreender, dizer, proclamar que teria podido escolher de outro modo e que, a qualquer momento, ainda pode fazê-lo." 2 (WEIL, 2011, p. 58: grifo do autor). Segundo Weil, o ser humano só é livre, quando ele se sabe livre. Parafraseando Kant, a liberdade é a ratio essendi da razão, e esta como que a ratio cognoscendi da liberdade (WEIL, 2011, p. 59). Assim, saber-se livre é condição imprescindível à determinação, porque, por um lado: “[...] uma liberdade que não soubesse que é liberdade seria simples indeterminação, e só seria isso por relação a um ser livre e assim capaz de pôr a questão da determinação." (WEIL, 2011, p. 59), e, por

${ }^{2}$ WEIL, Eric. Filosofia moral. São Paulo: É Realizações, 2011, p. 58.

NODARI, Paulo César. Razão e violência em Eric Weil. Griot : Revista de Filosofia, Amargosa, Bahia, v.16, n.2, p.188204 , dezembro/2017. 
outro lado, porque: "[...] uma razão que não fosse livre seria uma vontade de universalidade incapaz de escolher e não se conheceria, pois só um ser livre é capaz de buscar, vale dizer de se separar de si mesmo para se opor a sim mesmo." (WEIL, 2011, p. 59). Assim, em última análise, a razão reconhece que é incapaz de fundar-se a si mesma, nascendo e desenvolvendo-se a partir de uma decisão pela própria razão, a qual não poderia ser imposta por outras razões, senão, tão-somente, por uma decisão livre de exercício da razão. Assinala magistralmente Weil:

Nesse sentido, pode-se dizer e é preciso dizer que o homem é liberdade indeterminada e sempre se determinando: a liberdade pode aceitar, como pode recusar, a violência, ela pode situar-se do lado da animalidade, assim como pode desviar-se dela. Mas, e aqui está o ponto decisivo, o homem não pode falar dessa escolha, ele só pode descobrir (des-cobrir) depois de ter escolhido o discurso coerente e a razão. Vimos e vemos, é verdade, homens que optam, deliberadamente e após madura reflexão, contra a razão, num mundo que é informado por ela e que, pelo menos em princípio, organizou-se contra a violência; isso não constitui, entretanto, uma objeção: basta observar que, regularmente, esses homens justificam sua opção, que, por consequência, eles pressupõem o discurso antes de negá-lo; eles não poderiam negá-lo se ele não existisse. A recusa da razão se produz neles demasiado tarde: eles pretendem efetuar uma escolha razoável optando contra a razão; e eles aduzem razões "científicas" que tornam, segundo eles, essa decisão inevitável para quem, razoavelmente, se submete aos fatos. Malgrado eles mesmos, eles confirmam assim a tese: razão e violência só se separam para o homem depois da opção pela razão. Só o homem razoável sabe que é livre; só aquele que se voltou para a razão pode compreender, dizer, proclamar que teria podido escolher de outro modo e que, a qualquer momento, ainda pode fazê-lo. Uma vez que os homens optaram pelo discurso, a opção do indivíduo pela violência é função dessa escolha. Quanto ao que seria violento num mundo não-informado pela razão, ele não teria nenhuma consciência da sua escolha: ele seria um animal. (WEIL, 2011, p. 58: grifos do autor).

O ser humano visa à felicidade, isto é, ele quer ser feliz, sendo a felicidade, para Weil, o exercício da razão. É a conciliação do ser razoável consigo mesmo. "A ação moral é ação do ser razoável que quer pôr-se de acordo consigo mesmo." (WEIL, 2011b, p. 37). A felicidade é o exercício da razão, isto é, a razão não se constitui em um auxílio para chegar à felicidade, mas, antes, trata-se do próprio exercício da razão como já sendo o caminho da felicidade. "Não é, portanto, com a ajuda da razão que o homem buscará a felicidade: a razão, o exercício da razão, a razão realizada pelo próprio homem em si mesmo, é a felicidade." (WEIL, 2011, p. 61: grifos do autor). A felicidade é, por assim dizer, o exercício da razão. Trata-se do ser humano enquanto razoável que quer ser feliz, ainda que se reconheça e se saiba carente de desejos e necessidades, mas no exercício da liberdade racional. Sublinha Weil:

O homem moral, o homem da vontade razoável, não será feliz de uma felicidade estática; ele será feliz ao se moralizar. $O$ indivíduo, mesmo que se supere ao mais alto grau, nunca será mais que superação do indivíduo por ele

NODARI, Paulo César. Razão e violência em Eric Weil. Griot : Revista de Filosofia, Amargosa, Bahia, v.16, n.2, p.188204, dezembro/2017. 
mesmo, e toda ideia de felicidade adquirida, estabelecida, não agente é um sonho para ele: o indivíduo, por moral que seja, só é moral porque, sempre de novo, se encontra exposto à tentação, à paixão, ao perigo de anular e de trair o que a razão nele reconheceu como seu dever. É por isso que ele sabe que a cada momento pode ser feliz na medida em que o quiser. (2011, p. 134-135).

A felicidade que o homem busca, não é resultado de algo previamente estabelecido, mas de um caminho a ser percorrido, como uma coincidência, ou então, de um acordo razoável do ser consigo mesmo (WEIL, 2011b, p. 33). O ser humano que se deixaria mover totalmente pelos desejos, paixões, prazeres acabaria por dar primazia à sua condição de animal irracional, e, enquanto tal, estaria na linha do contentamento, mas não da felicidade, que é mais do que simples contentamento. Para o animal dado à irracionalidade não há felicidade, tão-somente contentamento, isto é, a realização dos prazeres e das paixões. A vontade do ser razoável à felicidade e não ao mero contentamento só pode ser concebida no mundo da razão. A felicidade é fruto da paz interior, ou seja, está acima das vontades do animal irracional e é exigência do ser razoável. "É o ser humano enquanto razoável que quer ser feliz - e só ele pode conceber esse desejo, essencialmente não animal." (WEIL, 2011, p. 61). Assim, a felicidade é exercício da razão, na medida em que é razão realizada pelo próprio ser humano na comunidade de vida histórica. Salienta Weil:

O homem não ignora que ele é carente, cheio de necessidades e carregado de tarefas, exposto a todos os sofrimentos do animal, do ser finito que não se basta; mas, mesmo aceitando sua condição, ele quer ser feliz; ele pede - ele sabe agora que é a si próprio que ele o pede - uma felicidade que só dependa de si mesmo; o que ele busca não é a simples abolição da infelicidade e da divisão pelo aniquilamento de todo conteúdo, do eu e do mundo (cf. § 9 c), mas uma felicidade positiva, um contentamento do qual ele possa estar seguro, um apaziguamento, senão permanente - pois o ser finito não poderia estar sem desejo ou necessidade em nenhum momento da sua existência empírica -, mas, em todo caso, um apaziguamento que a cada instante ele possa restituir a si mesmo ao reencontrar, quaisquer que sejam as circunstâncias exteriores, uma paz neste sentido imperdível. (WEIL, 2011, p. 60: grifos do autor).

O ser humano tem o dever de ser feliz, e ele só se torna moral à medida que cumpre o seu dever, dever de ser feliz. "O dever para consigo mesmo se determina como dever de ser feliz enquanto ser razoável." (WEIL, 2011, p. 131). A busca da felicidade é dever do ser humano para consigo mesmo. Isso só se torna possível, quando o ser humano conseguir predominância sobre seus instintos e seus desejos a razão, ou seja, o ser humano será razoável e feliz na medida em que suas forças limitadas conseguirem priorizar a razão sobre suas tendências, instintos e paixões. Assim, o dever que o ser humano tem de ser feliz se dá em razão de evitar a infelicidade, isto é, o outro da razão, a violência. $O$ ser humano, no âmbito da filosofia moral, recusa escolher o que não o torna feliz, recusa o que pode desviá-lo da fonte inesgotável da paz interior e da construção histórica da via da razoabilidade. Sublinha Camargo:

NODARI, Paulo César. Razão e violência em Eric Weil. Griot : Revista de Filosofia, Amargosa, Bahia, v.16, n.2, p.188204, dezembro/2017. 
Ele observa a regra moral, é ser razoável, escolhe ser feliz a partir da razão razoável. O cidadão razoável é o homem que faz que a regra dever para consigo mesmo se determine como dever de ser feliz. Assim, dever e felicidade são conceitos que devem ser pensados dialeticamente no contexto da moral da ação. $O$ dever não nega a felicidade, nem a refuta, pois é seu fundamento, sua interioridade. A felicidade é o outro lado do dever, é a exterioridade na qual se exprime o sentimento do dever. (2014, p. 93).

O dever para consigo mesmo levam-no ao dever para com outrem. Pelo dever que cada um tem de realizar sua felicidade tem-se o dever para com os outros seres humanos. "A felicidade do ser razoável só se realiza, o dever para consigo só se torna concreto no cumprimento dos deveres do ser razoável para com outros seres humanos, igualmente finitos e razoáveis." (WEIL, 2011,143). É honroso trabalhar não somente para a própria satisfação, mas para a satisfação e a felicidade de todos. O dever para com o outro é circunscrito pelo conceito de justiça (WEIL, 2011, p. 14). A justiça exige que se trate a outrem conforme cada um desejaria de ser tratado. "A justiça exprime assim o princípio da universalidade no interior do mundo histórico." (WEIL, 2011, p. 143). Ou seja, o dever de justiça é o princípio por excelência da universalidade no interior da comunidade histórica (CAMARGO, 2014, p. 100). E, fundado no conceito de justiça, surge o dever de prudência moral, resumo de todos os deveres fundados na justiça. "A justiça não é uma virtude que se pode, ou não, possuir; ela constitui uma obrigação absoluta para todo indivíduo que quer ser moral-obrigação absoluta e, por essa mesma razão, obrigação que é preciso interpretar a cada momento segundo a obrigação igualmente absoluta da prudência." (WEIL, 2011, p. 183). A prudência é uma virtude que engloba todas as outras. $O$ dever de prudência é sabedoria prática que garante o sucesso dos empreendimentos do indivíduo moral. Ela auxilia a distinguir as atitudes convenientes das inconvenientes, distinguir o ser moral do antimoral (CAMARGO, 2014, p. 100). Trata-se de um agir moralmente correto em vista do agir bem politicamente. "A prudência, dever que resume todos os outros, remete o homem, que pretende ser moral no mundo e neste mundo: não se é prudente na solidão absoluta, assim como não se é justo sozinho." (WEIL, 2011, p. 175). Nenhuma virtude nascerá na solidão absoluta, porque o dever para consigo só se efetiva no dever para com outrem em uma comunidade histórica, constituindo-se, pois, a virtude em nada mais e nada menos "[...] que a atitude de quem faz o seu dever." (WEIL, 2011, p. 175). Ou seja, noutros termos, poder-se-ia sublinhar com Weil:

Dever de prudência: o fato é que o homem moral tem um interesse no mundo, porque ele decidiu viver e agir no mundo. Entretanto, o ser moral não poderia reconhecer o valor e a validez de um interesse simplesmente dado pela simples razão de que é o seu. Seu interesse, enquanto ser moral, deve ser interesse de todo homem enquanto ser razoável. Ora, um único interesse corresponde a essa exigência, o da moral pura pela moralização da moral existente, pelo aparecimento de uma moral histórica superior: é do interesse da moral (pura) que todo mundo viva sendo a moral (concreta) que seja a melhor possível -

NODARI, Paulo César. Razão e violência em Eric Weil. Griot : Revista de Filosofia, Amargosa, Bahia, v.16, n.2, p.188204, dezembro/2017. 
possível, isto é, de modo que mesmo os que não põem o problema da moral sob a forma reflexiva, portanto, a massa da humanidade e, para começar, da comunidade reconheçam no que lhes é proposto uma forma de vida que lhes dá satisfação. O homem moral pecaria contra a prudência se esquecesse que a moral, hoje com na sua origem na noite dos tempos, procede do que não é moral, informa o que não é moral, tem a ver com o que não é moral: é da luta dos interesses naturais (dos interesses que, pelas diferentes morais, são considerados naturais e que não são sempre os mesmos: é natural ao homem ser histórico até naquilo que ele considera sua natureza e seu natural) que surge a moral como daí sempre surgiu: uma moral mais elevada só será admitida pelos homens se eles pensam encontrar nela seu interesse: se bastasse declarações dos filósofos e projetos não filosóficos de morais perfeitas, o problema teria desaparecido há muito tempo. O homem que quer ser moral não tem e não conhece para si escusas para ser imoral; ele as encontrará facilmente para os outros que têm interesses, desejos, necessidades "naturais", todos suficientes aos seus olhos para tornar ridículas, fantásticas, "idealistas" as exigências da moral: é neles que pensa o homem que quer a moral e sua justiça no mundo e para o mundo. (WEIL, 2011, p. 176).

O dever de felicidade que o ser humano tem para consigo e para com os outros caracteriza a vida informada pela moral. A moral informa a vida do ser humano, pois o guia pelo caminho da razão. Assim, a moral se torna efetiva na vida do ser humano. "A moral não quer simplesmente viver e ser vivida; o fato é que a partir do momento em que o homem põe a questão moral para si mesmo, ele quer moralizar-se por inteiro." (WEIL, 2011, p. 197). E aqui entra a relevância do dever, isto é, se o dever permanecer inimigo ou tirano do ser humano, este poderá até conhecer a moral, mas não será moral (WEIL, 2011, p. 197). E é nessa perspectiva que entra o conceito aristotélico de héxis, habitus. O ser humano se torna moral quando o cumprimento do dever se lhe torna natural, isto é, um estilo de vida, uma atitude espontânea (WEIL, 2011, p. 197-198). Encontra-se aí o conceito aristotélico de habitus que Weil procura resgatar. "O hábito designa a espontaneidade adquirida da ação e da reação moral, fruto da educação, do exercício prolongado, numa palavra: da vida moral. Este conceito pode ser também traduzido por segunda natureza, adquirida pelo indivíduo graças à educação, ao hábito de submeter a sua individualidade ao critério da universalidade." (PERINE, 1987, p. 232: grifos do autor).

Assim sendo, a moral não é simplesmente discursiva, mas torna-se uma forma de vida em vista da felicidade. A moral faz com que o ser humano assuma um compromisso para consigo mesmo e com o mundo, tornando a busca da felicidade razoável. Não se trata de uma vida moral em que o desespero romântico ou o desprezo universal diante da insuficiência prevalecem e são enaltecidos. Trata-se, no entanto, da aceitação corajosa dos limites e da vontade clara de, a partir do dado, transformá-lo, a fim de agir e reagir de um modo que não o leve à contradição consigo mesmo (WEIL, 2011, p. 198). É um dever, portanto, de responsabilidade que o ser humano tem diante de suas ações. O dever de agir moralmente é a atitude de quem aceita e quer o bem de si e de todos os outros.

NODARI, Paulo César. Razão e violência em Eric Weil. Griot : Revista de Filosofia, Amargosa, Bahia, v.16, n.2, p.188204, dezembro/2017. 
Quem se contenta em querer o bem sem fazer o necessário para realiza-lo é talvez o pior inimigo da moral, de toda vida moral: seu recurso às intenções puras e ineficazes desacredita até a ideia de moral, pois não só ele não age em vista da manutenção da moral existente, mas faz aparecer a moral formal à qual ele apela como a escusa mestra de todos os atos que a moral positiva considera como faltas. A boa intenção é indispensável, e não existe moral sem ela; para ser válida, ela deve ser intenção de bons resultados. (WEIL, 2011, p. 242-243).

A vida moral é guiada pela sabedoria prática que permite ao homem discernir, por meio da experiência e da reflexão, para chegar ao resultado por ele querido. A sabedoria prática, conceito resgatado da tradição grega, permite ao ser humano a compreensão de que a violência é um mal para si e para todos os seus semelhantes. É amparado pela reflexão, pela razão e compreensão, e não por suas paixões e instintos que o ser humano fará suas escolhas, e a primeira e fundamental escolha será a opção pela vida razoável, dizendo não à violência. A escolha pelo não à violência constitui-se o bem, a satisfação e a felicidade do ser humano moral.

A primeira e mais importante tarefa do indivíduo moral é se moralizar progressivamente, isto é, informar progressivamente suas paixões, interesses e tendências pela razão, de modo que transforme sua divisão interior de vontade de rebelião contra a razão em vontade de coincidência com ela. A moral quer informar a vida do indivíduo em sua totalidade, justamente porque quer informar o que não é moral e que, por isso mesmo, se refere à moral. Isso implica o trabalho constante do indivíduo, que sempre terá algo a submeter à razão [...]. (PERINE, 1987, p. 246).

A vida do ser humano moral é sempre amparada pela filosofia. É ela que está associada à busca de felicidade do ser humano. A filosofia, como reflexão e compreensão, torna o ser humano livre, porque ele se deixou informar pela razão. Afirma Weil:

A liberdade é a razão: só o ser razoável, não arbitrário, não violento, é livre e sabe que é livre, ao viver segundo uma lei que é sua e que reconhece como estabelecida por ele mesmo, só o ser livre pode se querer e ser razoável. Ele não coincide nunca com a razão, mas nada o impede de se elevar à razão, para a qual nada é por vir, para a qual, num presente que inclui ainda as estruturas essenciais desse eu empírico, tudo é pensável (dizível) e discurso e que, contudo, sempre advém. (WEIL, 2011, p. 290: grifo do autor).

Ou seja, uma vida moral é uma vida conduzida pela razão. Uma vida moral é uma vida fundada no dever de ser feliz como ser razoável. A felicidade é produto de uma vida informada pela moral. O ser humano moral cumpre seus deveres morais, tendo como primeiro o dever de não ser violento, e, nesse sentido, pode-se afirmar, segundo Perine (2004, p. 48), educar os seres humanos para a virtude é o mesmo que formá-los capazes de decidir e agir razoavelmente no seu respectivo lugar no mundo, isto é, “(...)

NODARI, Paulo César. Razão e violência em Eric Weil. Griot : Revista de Filosofia, Amargosa, Bahia, v.16, n.2, p.188204, dezembro/2017. 
segundo as exigências do universal na situação concreta, sabendo o que fazem e por que o fazem." (WEIL, 2011b, p. 67). Para Weil, a educação tem uma tarefa imprescindível.

\begin{abstract}
A tarefa da educação consiste em desenvolver no indivíduo a capacidade de compreender o que lhe diz respeito enquanto membro de uma comunidade humana (enquanto objetivamente "universalizado"), capacidade não só de fazer e dizer o que dele se exige, mas de compreender por que isto é exigido e, se for o caso, por que aquilo que efetivamente se exige não é exigível, seja por não se justificar tecnicamente, seja por mostrar-se injusto, sendo dirigido ao indivíduo isolado, não a todo o homem que desempenhe o mesmo papel no universal concreto da comunidade (sendo, portanto, exigência violenta). (WEIL, 2011b, p. 67: grifos do autor).
\end{abstract}

A educação deve formar um indivíduo para que ele, nas suas ações, leve em consideração o interesse universal concreto, o que a comunidade define, por seus costumes, regras e leis, como o seu interesse. "Ou seja, no fundo, o homem precisa se educar para aprender a ter domínio sobre os instintos de sua natureza animal, para dar lugar ao governo da humanidade em sua própria pessoa." (ASSIS, 2016, p. 217). Noutras palavras, a educação precisa estar focada na moralização e na humanização do ser humano, vivendo em uma comunidade. Ela não pode esquecer que a formação do ser humano se dá em uma comunidade de inserção. "A educação precisa trabalhar o indivíduo na perspectiva de socialização, de convivência com os demais." (ASSIS, 2016, p. 227). A educação precisa conduzir o indivíduo a compreender-se inserido e responsável ao que lhe diz respeito enquanto membro de uma comunidade humana.

A educação pretende, pois, formar indivíduos capazes de decidir e agir razoavelmente no seu lugar no mundo, isto é, segundo as exigências do universal na situação circunstanciada e concreta, sabendo, mas exatamente, o que fazem e por que o fazem (WEIL, 2011b, p. 67). A educação tem a finalidade de levar o indivíduo um agir razoável na história, isto é, ao processo progressivo de eliminação da violência na vida e nas relações humanas (CAMARGO, 2014, p. 113). A educação, segundo Camargo, “[...] visa a formar cidadãos capazes de decidir e agir razoavelmente, sabendo o que fazem e por que o fazem." (2014, p. 259). Em outras palavras, a educação foca a disposição virtuosa, portanto, firme e constante para a prática da razoabilidade, isto é, para a prática do agir bem. "É a retidão no modo de agir e na atitude prática que decide o valor do indivíduo e da educação que ele recebeu." (WEIL, 2011b, p. 62). Acentua, pois, com muita ênfase, Weil acerca da educação: "A educação não é, certamente, o que há de mais elevado; mas não se vê como seria possível, no plano da formação do homem, chegar ao cume sem partir da base." (WEIL, 2011b, p. 63: grifo do autor).

Por fim, não obstante saibamos ser a extinção e a extirpação da violência no e do mundo, por completo, impensável e inimaginável, por conta da liberdade que é inerente ao ser humano, e, enquanto tal, estando-lhe, por conseguinte, sempre aberta a condição de escolha, justamente, por ser livre, a possibilidade de opção do ser humano pela violência configura-se ainda e sempre como ameaça. É nessa perspectiva que se delineia a vocação, a tarefa e a missão imprescindíveis da educação, tanto em âmbito pessoal,

NODARI, Paulo César. Razão e violência em Eric Weil. Griot : Revista de Filosofia, Amargosa, Bahia, v.16, n.2, p.188204, dezembro/2017. 
quanto também, em âmbitos sociopolítico e cultural, porque, segundo Weil, "[...] o homem educado age convenientemente." (2011b, p. 64), isto é, ele será capaz de pensar, de decidir e de agir conforme as exigências da universalidade sem deixar de pertencer, de participar e tomar em conta a situação e a condição circunscritas de sua existência.

NODARI, Paulo César. Razão e violência em Eric Weil. Griot : Revista de Filosofia, Amargosa, Bahia, v.16, n.2, p.188204, dezembro/2017. 


\section{Referências bibliográficas}

CAMARCO, Sérgio de Siqueira. Filosofia e política em Éric Weil. Um estudo sobre a ideia de cidadania na filosofia política de Éric Weil. São Paulo: Loyola, 2014.

HERDER, Johann Gottfried. A palavra e o conceito humanidade. In: $O$ que é Esclarecimento? Immanuel Kant; Johann Benjamin Erhard; Johann Gottfried Herder; Gotthold Ephraim Lessing; Christoph Martin Wieland; Johann Georg Hamann; Moses Mendelssohn; Friedrich Schiller; Andreas Riem. [Tradução Paulo César Gil Ferreira; Revisão Marco Antonio Casanova]. Rio de Janeiro: Via Verita, 2011, pp. 73-74.

PERINE, Marcelo. Eric Weil e a compreensão do nosso tempo. Ética, política, filosofia. São Paulo: Loyola, 2004.

PERINE, Marcelo. Filosofia e violência. Sentidos e intenção da filosofia de Eric Weil. São Paulo: Loyola, 1987.

PERINE, Marcelo; COSTESKI, Evanildo (Orgs.). Violência, educação e globalização. Compreender o nosso tempo com Eric Weil. São Paulo: Loyola, 2016.

SAVADOGO, Mahamadé. O sentido da oposição entre razão e violência segundo Eric Weil. In: PERINE, Marcelo; COSTESKI, Evanildo (Orgs.). Violência, educação e globalização. Compreender o nosso tempo com Eric Weil. São Paulo: Loyola, 2016.

WEIL, Eric. Filosofia moral. São Paulo: É Realizações, 2011.

WEIL, Eric. Filosofia política. $2^{a}$ edição. São Paulo: Loyola, 2011 b.

WEIL, Eric. Lógica da filosofia. São Paulo: É Realizações, 2012.

Autor(a) para correspondência: Paulo César Nodari, Universidade de Caxias do Sul, R. Francisco Getúlio Vargas, 1130 - Petrópolis, CEP 95070-560, Caxias do Sul - RS, Brasil. paulocesarnodari@hotmail.com

NODARI, Paulo César. Razão e violência em Eric Weil. Griot : Revista de Filosofia, Amargosa, Bahia, v.16, n.2, p.188204 , dezembro/2017. 